\title{
IMPLIKASI KEBIJAKSANAAN YESUS BAGI GURU PENDIDIKAN AGAMA KRISTEN
}

\author{
Edi Purnama \\ Sekolah Tinggi Alkitab Tiranus \\ Jl. Cihanjuang Km. 5,2, Cihanjuang, Parongpong, Bandung Barat \\ edisimamora78@gmail.com
}

\begin{abstract}
ABSTRAK: Kebijaksanaan merupakan bagian dari aspek karakter guru yang perlu dimiliki. Menjadi guru bijaksana merupakan harapan semua guru. Namun, hal ini tidak mudah diterapkan dalam realitas sesungguhnya. Sebab situasi dan kondisi tertentu menjadikan guru bersikap dan bertindak tidak bijaksana sehingga menghasilkan respons yang tidak menyenangkan dari peserta didik. Hal ini merupakan pergulatan yang dialami para guru. Penelitian ini mendalami aspek-aspek kebijaksanaan Yesus Kristus dalam menyikapi setiap persoalan dengan tepat dan benar. Sosok Yesus Kristus adalah contoh ideal bagi seorang guru masa kini untuk diteladani dalam mengembangkan aspek kebijaksanaan. Dengan mempelajari kebijaksanaan Yesus, maka diharapkan guru Pendidikan Agama Kristen memiliki dorongan untuk lebih bersikap bijaksana. Mengingat pentingnya peranan guru, maka pertanyaan utama yang menjadi acuan dalam tulisan ini adalah apa nilai kebijaksanaan Yesus Kristus yang perlu dipahami dan dimiliki oleh guru Pendidikan Agama Kristen? Tujuan utama penelitian ini adalah memberikan usulan kepada guru Pendidikan Agama Kristen mengenai implikasi kebijaksanaan Yesus Kristus. Penelitian ini menggunakan metode kualitatif dengan melakukan studi teologis berupa studi hermeneutis untuk menggali kehidupan Yesus.
\end{abstract}

Kata Kunci: Kebijaksanaan, implikasi, guru Pendidikan Agama Kristen

\section{THE IMPLICATION OF JESUS' WISDOM FOR CHRISTIAN EDUCATION TEACHER}

\begin{abstract}
Wisdom is part of the aspects of teachers character that needs to be possessed. Being a wise teacher is the expectation of all teachers. However, it is not easy to be implemented in reality, since particular situations and conditions lead the teachers to act unwisely. It may produce an unpleasant response from the students. It is a struggle experienced by teachers. Therefore, the present research is trying to excavate some aspects of Jesus Christ's wisdom as he was addressing properly every problem surrounding him. The figure of Jesus Christ is an ideal example, to be emulated, for a teacher today in developing aspects of wisdom. By studying Jesus' wisdom, it is hoped that Christian Religious Education teachers will be encouraged to be more prudent. Considering the important role of the teacher, the main question that becomes the basis of this paper is what value of the wisdom of Jesus Christ needs to be understood and possessed by teachers of Christian Religious Education. The main purpose of this study is to suggest the teachers of Christian Religious Education the implications of the wisdom of Jesus Christ. This research uses a qualitative method by conducting a theological study in the form of a hermeneutical analysis to explore the life of Jesus.
\end{abstract}

Keywords: wisdom, implication, christian education teacher 


\section{PENDAHULUAN}

Price menyatakan bahwa kepribadian guru sangat penting karena keteladanan lebih bernilai dibandingkan dengan perkataan (2011, p. 1). Pernyataan Price di atas memberikan penegasan tentang arti sebuah kepribadian dan keteladanan. Dua kata ini memiliki keterkaitan satu dengan yang lainnya di mana kepribadian seorang guru memengaruhi perilaku dan tindakan yang dilakukan. Ini menegaskan bahwa guru perlu memiliki kepribadian yang baik sebagai syarat penting seorang pendidik.

Menyimak dan mencermati kondisi pendidikan di tanah air saat ini jauh dari harapan semestinya. Bukan tanpa alasan juga bahwa hal ini menjadi sesuatu yang memprihatinkan. Dunia pendidikan seharusnya menampilkan pemandangan yang indah karena situasi yang ditunjukkan membangun peradaban. Sebaliknya, akhirakhir ini dunia pendidikan menampilkan situasi yang jauh dari semestinya. Dalam dunia pendidikan, guru dan murid adalah sosok yang terlibat dalam proses belajar mengajar. Guru adalah sosok yang digugu dan ditiru. Digugu dan ditiru memiliki arti bahwa guru merupakan tokoh panutan karena menampilkan kebijaksanaan dalam bersikap maupun bertindak. Karena itu, guru adalah salah satu penentu kemajuan peradaban manusia. Bagaimana dengan sosok guru di era sekarang? Penulis meyakini masih ada guru yang memiliki kepribadian dan keteladanan yang baik. Dalam hal ini, penulis menekankan pada guru yang tidak menampilkan kepribadian dan keteladanan yang baik.

Beberapa kasus menengarai anggapan bahwa guru tidak bersikap dan tidak bertindak bijaksana. Guru di kawasan Bekasi Barat terpaksa dilaporkan oleh wali murid atas tuduhan penganiayaan terhadap anak didik kepada pihak berwajib. Guru tersebut melakukan tindak kekerasan dengan menendang dan mencubit anak didik yang merupakan anak berkebutuhan khusus. Tindakan penganiayaan tersebut dilakukan karena anak didik tersebut tidak membawa buku matematika (Nugroho, 2019). Kasus yang tidak jauh berbeda pun terjadi di Samarinda. Guru DN, seorang guru PAUD, menganiaya muridnya yang berusia 4,5 tahun. Kasus tersebut terjadi disebabkan murid tidak mau mengeja huruf yang diminta oleh guru DN. Juanlie Totong, kuasa hukum korban menyatakan, "Jadi wajah kiri dan kanan korban terlihat biru-biru setelah dijemput ayahnya. Di rumah ditanya ibunya dipukul gurunya." Kasus ini pun berujung pada laporan orang tua korban ke kepolisian (Rosadi, 2019).

Munculnya kasus-kasus di atas telah memberikan anggapan bahwa ada guru yang bersikap tidak bijaksana. Kasus-kasus di atas, memunculkan pertanyaan mendasar. Adakah yang salah dalam dunia pendidikan di Indonesia? Sistem pendidikan dan pembekalan guru yang tidak memadaikah? Apakah ada cara yang lebih tepat dalam menyikapi sikap dan tindakan siswa? Artikel ini mencoba mendeskripsikan kebijaksanaan Yesus sebagai Guru Agung dan memberikan implikasi kepada guru masa kini. Setidaknya, penelitian ini mencoba memberikan sumbangsih terhadap fenomena situasi perilaku guru terhadap peserta didik dengan meneladani Yesus yang merupakan Guru Agung.

\section{METODE}

Metode yang digunakan dalam penelitian ini adalah metode kualitatif yang bersifat deskriptif. Sugiyono menyatakan bahwa penelitian kualitatif yang bersifat deskriptif menekankan pada proses daripada 
produk atau outcome, dan analisis data dilakukan secara induktif (2014, pp. 9-10).

Penelitian ini juga menggunakan studi teologis dengan cara studi teks bahasa asli Alkitab, yakni bahasa Yunani mengenai etimologi 'bijaksana' dari Perjanjian Baru dan melakukan studi hermeneutika. Sutanto menyatakan bahwa studi hermeneutik perlu dilakukan untuk memikirkan konsep-konsep dan prinsip-prinsip dalam menafsirkan Alkitab (2007, p. 3). Proses analisis teks dilakukan dengan melakukan studi hermeneutik terhadap teks keempat Injil untuk menggali kebijaksanaan Yesus dari beberapa peristiwa yang terjadi, melihat latar belakang teks dan konteks, serta melakukan komparasi terhadap beberapa literatur yang telah ada.

Hasil analisis terhadap teks-teks tersebut kemudian disusun dan dibuat implikasi dari setiap prinsip-prinsip yang diperoleh. Penulis pun melakukan kajian pustaka untuk lebih mendalami sosok Yesus sebagai Guru Agung dengan pendekatan deskriptis-analitis.

\section{HASIL DAN PEMBAHASAN/ISI (KAPITAL, BOLD, FONT 11)}

Dalam bagian ini akan diulas studi teks etimologi "bijaksana" berdasarkan bahasa Yunani. Pembahasan pun akan mengulas Perjanjian Baru dan implikasi bagi guru masa kini di Indonesia.

\section{Terminologi Bijaksana dalam Perjanjian Baru}

Perjanjian Baru menggunakan kata sophia untuk terminologi kata hikmat yang artinya kebijaksanaan. Kata sophia muncul 51 kali dalam Perjanjian Baru (Mat. 11:19, 12:42, 13:54; Mrk. 6:2; Luk. 2:40, 2:52, 7:35; Kis. 6:3, 6:10, 7:10; Rm. 11:33; 1 Kor. 1:17; 2 Kor. 1:12; Ef. 1:8; Yak. 1:5, dsb). Arti utama dari kata sophia adalah 'hikmat; ilmu; dan kepandaian' (Sutanto, 2004, p. 712). Kata ini berasal dari kata 'sophós' yang artinya 'yang berhikmat, yang berpendidikan, yang pandai' (Sutanto, 2004, p. 712).

Zodhiates dalam The Hebrew-Greek Key Study Bible menjelaskan arti dasar sophos, "Therefore, in its basic meaning sophos is the one who knows how to regulate his course in view of movement of the heavens or of God" (1984, p. 1729). Kata sophós muncul 20 kali dalam Perjanjian Baru (Mat. 11:25, 23:34; Luk. 10:21; Rm. 1:14, 1:22; 1 Kor. 1:19; Ef. 5:15; Yak. 3:13, dsb). Sedangkan untuk kata sophia, Zodhiates dalam The Complete Word Study Dictionary New Testament memberikan deskripsi yakni:

In a higher sense, wisdom, deep knowledge, natural and moral insight, learning, science, implying cultivation of mind and enlightened understanding ... The Wisdom of God means the divine wisdom, including the ideas of infinite skill, insight, knowledge, purity (1992, p. 1300-1301).

Menyimak deskripsi yang diberikan Zodhiates, maka setiap orang memerlukan kebijaksanaan Ilahi. Kebijaksanaan bukan sekadar keahlian, melainkan sikap memahami situasi dan kondisi dengan pemahaman yang benar dan tepat. Lebih lanjut, dalam kebijaksanaan terkandung ketajaman berpikir dan wawasan yang luas memahami situasi dan kondisi yang ada. Ensiklopedia Alkitab Masa Kini Jilid 1 menyatakan hikmat jarang netral (1992, p. 390). Disebut jarang netral karena hikmat mengandung filosofi yang mendasarinya. Ini terlihat dari penjelasan Stefanus di hadapan Imam Besar, "Dan Musa dididik dalam segala hikmat orang Mesir, dan ia berkuasa dalam perkataan dan perbuatannya" (Kis. 7:22). 
Matthew Henry memberikan komentar perihal ini,

He was learned in all the wisdom of the Egyptians, who were then famed for all manner of polite literature, particularly philosophy, astronomy, and (which perhaps helped to lead them to idolatry) hieroglyphics. Moses, having his education at court, had opportunity of improving himself by the best books, tutors, and conversation, in all the art and sciences, and had a genius for them. Only we have reason to think that he had not so far forgotten the God of his fathers as to acquaint himself with the unlawful studies and practices of the magicians of Egypt, any further than was necessary to the confuting of them (1992b, p. 66).

Menyimak komentar Henry, maka dapat diduga bahwa Musa dididik pula berdasarkan filsafat agama-agama Mesir pada masa itu. Artinya Musa telah menerima ajaran-ajaran hikmat orang Mesir, termasuk konsepsi penyembahan berhala yang ada di dalamnya. Ensiklopedia Alkitab Masa Kini Jilid I memberikan penjelasan mengenai hikmat, yakni:

la adalah karunia Allah atau melawan Allah. Kalau hikmat diceraikan dari penyataan Allah, maka hikmat itu dipermiskin kalau tidak hendak disebut dimandulkan (1 Kor. 1:17; 2:4; 2 Kor. 1:12) dan bodoh atau, paling jelek, malah jahat (1 Kor. 1:19 dab; Yak. 3:15 dab). Kebijakan duniawi didasarkan pada pranata dan pengalaman tanpa penyataan, dan dengan demikian sangat terbatas. Kegagalan untuk mengakui keterbatasan-keterbatasan itu mendatangkan penghukuman alkitabiah atas semua (terutama orang Yunani) yang dengan sombong berusaha mengatasi masalah-masalah rohani dengan hikmat manusia (1992, p. 392).
Ini menjelaskan bahwa hikmat dapat diperoleh dari manapun, termasuk dari unsur keagamaan. Unsur-unsur keagamaan telah berkembang pada masa Perjanjian Baru. Perkembangan tersebut dapat dilihat pada: pemujaan kaisar, munculnya agama-agama rahasia, pemujaan alam gaib, dan filsafatfilsafat. Semua praktik keagamaan ini memberikan hikmat bagi pemeluknya. Contoh, pemujaan alam gaib. Tenney menjelaskan bahwa sejak awal berdirinya kota Roma, orang Romawi sudah menujum atau meramal masa depan dengan melihat isi perut binatang yang baru disembelih (2013, p. 86). Ini berarti orang Roma mendasarkan penyelesaian persoalan pada ahli nujum yang dapat meramal.

Di samping unsur keagamaan, filsafat juga mendapat tempat yang penting pada masa itu. Sebut saja Platonisme, Gnostik, Neo-Platonisme, Epikurianisme, Stoicisme, Sinisme, dan Skeptisisme (2013, pp. 90-97). Tenney menjelaskan lebih lanjut mengenai Platonisme bahwa bagi Platonisme, pengetahuan adalah keselamatan; dosa adalah kebodohan. Dengan mencari Kebaikan yang Tertinggi, Sang Akhir, Gagasan yang Agung, orang dapat membebaskan dirinya dari belenggu dunia materi dan dapat mencapai pengertian tentang dunia yang sesungguhnya (2013, p. 91).

Hikmat yang utama bagi filsafat ini adalah pengetahuan. Artinya pengetahuan menjadi dasar bagi pengambilan keputusan. Dengan kata lain, unsur manusia mendominasi dalam kehidupan dan pengambilan keputusan sehingga manusia tidak bergantung pada Allah. Sebab filsafat telah menggantikan posisi sentral Allah menjadi yang utama. Sebaliknya, penelitian ini mengarahkan seseorang mengambil keputusan berdasarkan patron Allah dengan 
memerhatikan beberapa aspek, yaitu aspek teologis, psikologis, sosial, dan moral. Yakobus 3:17 menyatakan, "Tetapi hikmat yang dari atas adalah pertama-tama murni, selanjutnya pendamai, peramah, penurut, penuh belas kasihan dan buah-buah yang baik, tidak memihak dan tidak munafik." Karena itu, pengertian hikmat dalam penelitian ini terkait kebijaksanaan Yesus yang memahami situasi dan kondisi dengan pemahaman yang benar dan tepat serta ketajaman berpikir atas dasar pertimbangan moralitas sehingga dapat mengambil keputusan berdasarkan firman Allah.

\section{Yesus adalah Sang Hikmat}

Yesus Kristus adalah sosok utama dan pusat iman Kristen. Dia adalah sosok fenomenal di kalangan kawan maupun lawan. Hikmat-Nya tak tertandingi membuat kawan dan lawan segan terhadap diri-Nya. Bila membaca Injil, maka kita akan menyaksikan keindahan hikmat Yesus Kristus. Seringkali hikmat Yesus Kristus dinyatakan dalam situasi-situasi genting dan membahayakan diri-Nya. Walaupun demikian, keindahan hikmat-Nya tidak dapat dibungkam. Sebaliknya, musuh-musuh yang berusaha menjebak dan membunuhnya dibuat bungkan dan terpana. Kualitas hikmat ini memunculkan pertanyaan bagi para musuhnya, siapakah Yesus Kristus sesungguhnya? Nampaknya tidak berlebihan bila menyebut Yesus Kristus adalah Sang Hikmat jika mengacu pada kualitas tersebut. Ensiklopedia Alkitab Masa Kini I menyatakan,

Dua kali la mempersonifikasikan hikmat dengan cara yang mengingatkan orang pada Ams; Mat. 11:19 (= Luk. 7:35) dan Luk. 11:49 (Mat. 23:34 dab). Dalam kedua ayat itu Kristus mungkin mengacu pada diri-
Nya sebagai 'Hikmat' meskipun itu tidak pasti ... (1992, p. 392).

Pendapat tersebut bukan tanpa alasan, sebab Yesus sendiri mengidentikkan diri-Nya dengan hikmat, "...Sebab ratu ini datang dari ujung bumi untuk mendengar hikmat Salomo, dan sesungguhnya yang ada di sini lebih dari pada Salomo!" (Mat. 12:42). Sekalipun tidak ada pernyataan eksplisit bahwa diri-Nya adalah Sang Hikmat, tetapi nampaknya kalimat "yang ada di sini lebih dari pada Salomo" menegaskan bahwa diri-Nya adalah Sang Hikmat. Kata "lebih" dalam terjemahan bahasa Indonesia tidak dapat menggambarkan secara khusus kehebatan dan luar biasanya hikmat Yesus. King James Version menggunakan kata 'greater than' yang memiliki arti "more excellent; greater in quality" lebih tepat menggambarkannya. Memang Salomo memiliki hikmat yang hebat pada zaman-Nya, tetapi Yesus memiliki hikmat melebihi segala hikmat yang dimiliki Salomo. Hikmat Yesus dijabarkan melalui tindakan nyata dengan memerhatikan aspek moral, sosial, psikologis dan teologis sehingga sikap dan tindakan serta keputusan Yesus bersifat komprehensif yang tidak menjadi jerat bagi diri-Nya, tetapi juga memberikan kemaslahatan bagi banyak orang. Ini pun memberikan pembelajaran bagi para murid bagaimana hikmat Yesus dinyatakan dalam beragam peristiwa yang dirangkum dalam Injil.

\section{Yesus Kristus adalah Allah}

Satu-satunya alasan mendasar mengapa Yesus melebihi Salomo karena Dia adalah Allah. Kesimpulan demikian diperoleh melalui teks Injil yang menyatakan, 
"Pada mulanya adalah Firman; Firman itu bersama-sama dengan Allah dan Firman itu adalah Allah...Firman itu telah menjadi manusia, dan diam di antara kita, dan kita telah melihat kemuliaan-Nya, yaitu kemuliaan yang diberikan kepada-Nya sebagai Anak Tunggal Bapa, penuh kasih karunia dan kebenaran" (Yoh. 1:1, 14).

Teks Injil ini memberikan konsepsi bahwa Yesus memiliki dua natur, yaitu Allah dan manusia. Kedua natur ini menjadi diskusi yang tiada henti mengingat kompleksitas yang dimiliki Yesus Kristus. Bowman dan Komoszweski dalam menempatkan Yesus di Tahta-Nya menguraikan natur Yesus adalah Allah dengan menjelaskan beberapa kriteria yang ditinjau dari sifat, nama, kehormatan, perbuatan, dan kedudukan-Nya (2015, p. 22). Menurut hemat penulis, kriteria yang disampaikan Bowman dan Komoszweski dapat menjadi tolok ukur untuk menguji natur Yesus. Hal ini akan menghindarkan spekulasi dari banyak orang tentang natur Yesus. Sekalipun Yesus mengidentikkan diri-Nya sebagai Guru, tetapi hakikat Yesus sesungguhnya adalah Allah. Ini yang membedakan Yesus dengan manusia. Dengan demikian, hikmat Yesus Sang Guru melebihi hikmat sang raja (Salomo).

Mengenai hal tersebut, Yesus mengungkapkan jati diri-Nya secara eksplisit dengan berkata, "Kamu menyebut Aku Guru dan Tuhan, dan katamu itu tepat, sebab memang Akulah Guru dan Tuhan" (Yoh. 13:13). Kata "Guru" dan "Tuhan" berasal dari kata Yunani didaskalos dan kurios. Barclay sebagaimana dikutip Jonch menulis dalam catatan kaki bahwa kata guru (didaskalos), rabi (rabbi) dan tuan (kurios) dalam Injil Yohanes (sebagian besar) adalah sinonim. Kata rabi ini secara harfiah berarti orang besarku (my great one). Kata ini merupakan satu gelar kehormatan yang diberikan seorang murid kepada seorang guru Taurat, atau para pencari ilmu kepada para bijak (2007, p. 259). Dua kata ini ingin menekankan bahwa Yesus adalah orang yang dihormati. Namun, kata kurios lebih menekankan tentang Ketuhanan Yesus. Istilah Yunani Kurios di dalam LXX adalah terjemahan dari kata Ibrani Adonai atau Yahweh. Sedangkan bahasa Aram untuk Kyrios adalah Mar. Dalam LXX Kurios muncul lebih dari 9000 kali, dimana kira-kira 6156 kali di antaranya dipakai untuk menerjemahkan sebutan Yahweh (Notomiharjo, 1995). Lebih lanjut, Notomiharjo menyatakan bahwa gereja mula-mula menggunakan kata kurios sebagai sebutan yang menunjukkan Ketuhanan Yesus secara absolut, bukan lagi sebagai panggilan umum sebagaimana yang dipahami murid-murid pada masa itu (1995, p. 79). Ini memiliki implikasi teologis bahwa Yesus bukan sekadar orang yang perlu dihormati sebagai guru semata, melainkan Dia harus mendapatkan penghormatan secara absolut sebab Dia adalah Tuhan. Hal ini yang ditekankan Paulus juga dalam suratsuratnya (Rm. 10:9; Flp. 2:9; dan 1 Kor. 12:3). Notomiharjo mengutip pendapat Fitzmyer mengenai kata kurios yang dikemukakan Paulus tentang Yesus,

When Paul uses Kyrios of Jesus, he expresses the latter's actual dominion over men precisely ini his glorious, risen condition as an influence vitally affecting the lives of Christians. It does not denote Christ's role in his earthly condition, nor even his role in eschatological parousia, but rather his present condition as the Risen Lord (1995).

Fakta ini menolong untuk memahami hakikat Yesus sesungguhnya bahwa Dia 
adalah Allah. Penulis Amsal menyatakan, "Aku, hikmat, tinggal bersama-sama dengan kecerdasan, dan aku mendapat pengetahuan dan kebijaksanaan" (Ams. 8:12). Kata 'Aku' merupakan bentuk personifikasi. Rhodes menyatakan, "Personifikasi adalah kiasan retoris di mana benda mati atau konsep yang abstrak diberikan kualitas manusia atau diwakili oleh bentuk seperti manusia" (2016, p. 123). Mengacu pada pengertian yang disampaikan Rhodes, maka nampaknya hikmat di sini merujuk pada satu pribadi, bukan sekadar merujuk pada arti pikiran atau pengetahuan. Sekalipun Rhodes tidak menyatakan bahwa bagian dari Amsal 8 dapat ditafsirkan Kristus. Memang perlu diakui bahwa teks Amsal 8:12 memiliki kesulitan tersendiri tatkala hendak ditafsirkan bila dijelaskan tanpa menggunakan perspektif Perjanjian Baru. Namun, Henry memiliki pendapat berbeda berkenaan dengan hal ini. Hikmat tersebut mengacu pada Kristus. Henry memberikan komentar terkait hal ini,

Wisdom here is Christ, in whom are hidden all the treasures of wisdom and knowledge; it is Christ in the word and Christ in the heart, not only Christ revealed to us, but Christ revealed in us. It is the word of God, the whole compass of divine revelation; it is God the Word, in whom all divine revelation centres; it is the soul formed by the word; it is Christ formed in the soul; it is religion in the purity and power of it. Glorious things are here spoken of this excellent person, this excellent thing (1992a, p. 682).

Menyimak penjelasan Henry, maka Yesus bukan saja dinyatakan kepada kita, tetapi juga dinyatakan di dalam kita. Dengan kata lain, Yesus adalah Allah dan Sang Hikmat itu sendiri. Dalam hal ini, setiap orang yang memerlukan hikmat perlu datang kepada sumber hikmat yakni Yesus Kristus.

\section{Yesus adalah Pribadi Pembelajar}

Dengan hakikat-Nya yang adalah Tuhan, apakah lantas Yesus tidak pernah belajar? Orang Yahudi sangat ketat dalam pendidikan. Mereka tidak memiliki apapun pada masa penjajahan, kecuali memelihara pendidikan yang baik. Ini berlangsung baik dalam ruang lingkup sederhana sampai lingkup luas, yakni sekolah. Orang Yahudi memiliki tradisi mengajarkan Shema atau pengakuan iman Yahudi dalam keluarga (UI. 6:4). Seorang anak Yahudi diajarkan beberapa ayat dari kitab Taurat dan menghafalnya, beberapa amsal sederhana, dan beberapa ayat pilihan dari Mazmur. Orang-orang Yahudi memiliki semangat belajar yang tinggi, itu adalah ciri dalam kehidupan Yahudi.

Menyangkut hal itu, Tenney mengutip pernyataan Moore:

Upaya untuk mendidik seluruh rakyat dalam pengetahuan keagamaannya menimbulkan suatu sistem pendidikan semesta yang unik, yang unsur-unsurnya tidak hanya terdiri dari membaca dan menulis, tetapi juga suatu pelajaran bahasa kuno beserta kesusasteraan klasiknya. Nilai-nilai intelektual serta keagamaan yang tinggi yang diterapkan oleh pendidikan akan membekas selamanya dalam ingatan, dan dapat dikatakan dalam watak bangsa Yahudi, dan lembaga yang diciptakan untuk itu tetap bertahan hingga hari ini (2013, p. 123).

Walaupun demikian, Yesus tidak pernah menempuh pendidikan formal untuk menjadi rabi atau guru. Sekalipun la tidak menempuh pendidikan formal sebagaimana dilakukan rabi pada umumnya, tetapi orang- 
orang Yahudi mengagumi kecerdasan-Nya. "Maka heranlah orang-orang Yahudi dan berkata: 'Bagaimanakah orang ini mempunyai pengetahuan demikian tanpa belajar!'” (Yoh. 7:15). Menurut Keller sebagaimana dikutip Jonch (2007, pp. 262263), kemungkinan pengetahuan yang dimiliki Yesus berasal dari Yusuf dan Maria. Selain itu, kemungkinan Yesus menghadiri satu sekolah dasar (bet sefer/house of reading) yang dilaksanakan dalam sinagoge di pedesaan. Di sini la mungkin belajar Alkitab Ibrani, membaca dan menulis yang umum dipelajari dalam pendidikan dasar. Sangat mungkin, Yesus juga telah menghadiri satu sekolah sekunder (bet tahmud/house of learning) di mana la belajar hukum lisan yaitu halakah. Pada tahapan yang lebih tinggi lagi, Yesus kemungkinan juga telah menghadiri satu yeshiva atau bet midrash di mana la mendapatkan pelajaran yang lebih tinggi. Sebab di bet midrash diajarkan bagaimana berpikir logis, bernalar, dan menyelidiki teksteks kitab Ibrani (Karnawati, Hosana, \& Darmawan, 2019).

Fakta tersebut menunjukkan bahwa Yesus adalah seorang pembelajar yang aktif. la menjalani proses belajar sebagaimana manusia pada umumnya. Elia menyatakan bahwa perkembangan Yesus terjadi secara normal sebagaimana manusia pada umumnya (2001, p. 239). Kecerdasan-Nya bukan muncul begitu saja, tetapi melalui proses belajar sekalipun tidak menempuh pendidikan sebagai rabi. Hikmat-Nya tercermin dari cara Yesus menyelesaikan setiap persoalan yang dihadapkan kepadaNya baik dengan motif murni maupun motif terselubung. Hal ini tidak menyurutkan Yesus untuk menolong dan memberikan tanggapan terhadap permasalahan yang terjadi.

Gunther Bornkamm, seorang pakar Perjanjian Baru, sebagaimana dikutip Ismail menyimpulkan bahwa Tuhan Yesus menguasai Ibrani klasik yang digunakan dalam kitab-kitab suci, bahasa Ibrani Rabinik yang digunakan di kalangan golongan terpelajar, dan bahasa Yunani, sebab terbukti Tuhan Yesus mampu berdiskusi dengan para ahli Taurat tentang kitab-kitab klasik. Demikian juga Lewis Sherrill sebagaimana dikutip Ismail menyatakan bahwa Yesus menguasai tulisan-tulisan klasik seperti apokrifa pseudopigrafa. Yesus terus bersekolah sambil bekerja sebagai tukang kayu pada masa usia remaja dan pemuda (2014, pp. 65-66). Di samping itu, minat Yesus terhadap pembelajaran telah terlihat sejak masa kecilnya. Alkitab menyatakan,

...la sedang duduk di tengah-tengah alim ulama, sambil mendengarkan mereka dan mengajukan pertanyaan-pertanyaan kepada mereka. Dan semua orang yang mendengar Dia sangat heran akan kecerdasan-Nya dan segala jawab yang diberikan-Nya (Luk. 2:46-47).

Sekalipun Yesus adalah Anak Allah, tetapi la tetap membiasakan diri-Nya belajar. Belajar merupakan bagian penting dalam mengembangkan intelegensi-Nya. Dengan belajar kecerdasan dan kebijaksanaan, Yesus menjadi terasah dan terarah. Karena itu, Ibrani 5:8 menyatakan, "Dan sekalipun la adalah Anak, la telah belajar menjadi taat dari apa yang diderita-Nya." Kata "belajar" berasal dari kata Yunani manthano, yang memiliki arti meningkatkan pengetahuan, belajar dengan melakukan dan praktik (Sutanto, 2004, p. 501). Hal senada juga disampaikan Sidjabat dalam Mengajar Secara Profesional yang mengutip arti manthano 'belajar melalui praktek, perbuatan, dan pengalaman' (2011, p. 28). Dalam hal ini, Yesus mengembangkan keduanya. Dia belajar secara teori, tetapi Dia 
pun belajar melalui praktik kehidupan seharihari. Proses pembelajaran ini menjadikan Yesus sangat bijak menyikapi setiap permasalahan yang muncul, karena di samping teori yang dibaca, la pun menerapkan dalam situasi-situasi krusial dan mengherankan banyak orang atas hikmat yang dimiliki-Nya. Karena itu, Yesus mengenal murid-murid-Nya dan mengetahui cara terbaik memperlakukan serta mendoakan mereka.

\section{Aktualisasi Kebijaksanaan Yesus}

Injil mengungkapkan fakta bagaimana Yesus menunjukkan hikmat-Nya di tengahtengah komunitas Yahudi maupun di internal murid-murid. Fakta ini menjelaskan bahwa Yesus tidak sekadar menyebut diri-Nya lebih berhikmat dari pada Salomo, tetapi Yesus membuktikannya saat menghadapi kasuskasus yang pelik dan membutuhkan pengetahuan serta kecerdasan tingkat tinggi. Ada beberapa kasus krusial yang menunjukkan hikmat Yesus di tengah-tengah situasi pelik dan dapat memberikan jawaban dengan cermat, hati-hati, dan bijaksana:

\section{Keinginan Menjadi Terbesar (Mat. 18:1-5).}

Keinginan ini tidak muncul begitu saja, tetapi ada faktor pemicu sehingga muncul keinginan untuk menjadi terbesar. Dapat diduga bahwa keinginan menjadi terbesar muncul setelah pengakuan Petrus bahwa Yesus adalah Mesias, Anak Allah yang hidup (Mat. 16:16). Dalam hal ini, kerabian Yesus bukan menjadi yang utama, sebab kerabian tidak memiliki kepentingan politik di dalamnya. Persepsi orang Yahudi pada umumnya tentang mesias adalah seorang tokoh politik dan seorang pemimpin pemberontakan (Morris, 2006, p. 172). Dengan pemahaman demikian, maka muridmurid memiliki persepsi bahwa ketika menjadi murid Yesus, maka mereka akan menempati posisi strategis dalam pemerintahan Yesus. Rupanya keinginan para murid tersebut ditindaklanjuti dalam bentuk permintaan secara eksplisit yang disampaikan ibu Yakobus dan Yohanes bagi putra-putranya.

Reaksi pun muncul dari murid-murid. Ini menimbulkan sengketa di antara mereka (Mat. 20:20-28). Namun, Yesus menyikapinya dengan bijaksana dan tenang sembari berkata, "Kamu tidak tahu, apa yang kamu minta..." (Mat. 20:22). Yesus berbicara hal yang prinsip dan esensi, sedangkan ibu Yakobus dan Yohanes berbicara tentang posisi. Perbedaan prinsip ini terjawab dalam jawaban Yesus selanjutnya, "sama seperti Anak Manusia datang bukan untuk dilayani, melainkan untuk melayani dan untuk memberikan nyawa-Nya menjadi tebusan bagi banyak orang" (Mat. 20:28). Yesus tidak menjawab secara teknis, melainkan secara prinsip. Selain itu, Yesus ingin mengajar murid-murid untuk rendah hati. Green dalam The Message of Matthew menyatakan, "...I do not think many Christians would come up with this quality, which Jesus wants to see as the first and foremost characteristic of his disciples: humility" (2000, p. 190). Tafsiran Alkitab Masa Kini 3 menyatakan mengenai kerendahan hati, "Menjadi seperti anak kecil: terutama dalam hal ketergantungan dan kerendahan hati" (1982, p. 105).

Menjawab permintaan tidak selalu harus memenuhi permintaan itu bila mengetahui maksud dan tujuannya. Sikap bijaksana Yesus tercermin dari jawaban yang diberikan-Nya. Bukan mengabulkan, melainkan mengarahkan murid menjadi pribadi yang rendah hati sekalipun orientasi Yesus tidak diarahkan pada kepentingan politik, melainkan pada Kerajaan Allah. Dengan demikian, Yesus mengarahkan para 
murid kepada hal yang prinsip, bukan sekadar teknis. Ini memberikan pelajaran bahwa sikap dan tindakan bijaksana seorang guru tidak harus selalu memenuhi permintaan murid. Walaupun demikian, penolakan tersebut juga harus memiliki dasar dan alasan jelas sehingga murid-murid dapat menerima penolakan tersebut secara positif. Di samping itu, respons seorang guru yang bijak adalah tidak terburu-buru dalam membuat keputusan, melainkan memikirkan dan mempertimbangkan segala sesuatu, sehingga keputusan yang diambil tidak keliru dan merugikan pihak manapun. Sekalipun keputusan tersebut tidak dapat menyenangkan semua pihak.

\section{Membayar Pajak (Mat. 22:15-22)}

Pada bagian ini Yesus diperhadapkan pada situasi yang tidak mudah mengingat orang Farisi memberikan pertanyaan yang bersifat menjebak. Setidaknya, orang Farisi melancarkan dua strategi utama pada bagian ini. Pertama, memberikan pujian kepada Yesus dengan melihat pengajaran dan perbuatan Yesus. "Guru, kami tahu, Engkau adalah seorang yang jujur dan dengan jujur mengajar jalan Allah dan Engkau tidak takut kepada siapa pun juga, sebab Engkau tidak mencari muka" (ay. 16). Dapat dibayangkan bahwa barangkali orang-orang Farisi berpikir Yesus akan terbuai dan terlena dengan pujian tersebut sehingga kehilangan logika sehatNya dalam memberikan jawaban. Atas pujian tersebut, Yesus memberikan tanggapan yang tidak pernah dibayangkan sebelumnya oleh orang Farisi. Alih-alih memberikan respons sembari terbuai dengan pujian orang Farisi, justru Yesus mengkritik dengan keras dan berkata, "Mengapa engkau mencobai Aku, hai orang-orang munafik?" (ay. 18). Secara psikologis, manusia senang dipuji dan dapat terbuai dengan pujian tersebut. Tetapi Yesus tidak terbuai dengan pujian. Sebaliknya, Yesus tidak memedulikan pujian tersebut. Bagian ini mengajarkan agar berhati-hati terhadap setiap pujian agar dapat membedakan pujian yang tulus atau pujian yang mengandung jerat. Yesus dapat membedakannya karena Yesus mengetahui kejahatan hati mereka (ay. 18).

Kedua, mengajukan pertanyaan menjebak. "Apakah diperbolehkan membayar pajak kepada Kaisar atau tidak?" Ini bentuk pertanyaan tertutup yang menuntut jawaban ya atau tidak. Bila Yesus menjawab ya, maka orang Yahudi akan memandang Yesus sebagai pengkhianat karena mendukung penjajah pada masa itu. Dengan demikian, anggapan bahwa Dia adalah nabi atau Guru patut dipertanyakan. Namun, bila Yesus menjawab tidak, maka Yesus akan berhadapan dengan hukum Romawi yang berkuasa pada masa itu. Posisi Yesus dilematis dan tidak mudah untuk menjawabnya. Green menggunakan kata 'licik' untuk menggambarkan rencana jahat orang Farisi. Setidaknya, Green memberikan pendapatnya bahwa ada tiga peristiwa antara Yesus dan orang Farisi, yaitu mengenai politik, hidup setelah kematian, dan hukum yang terutama (2000, pp. 233-237). Hal ini adalah upaya-upaya yang dilakukan orang Farisi untuk menjebak Yesus dengan tipu muslihat.

Tafsiran Alkitab Masa Kini 3 menjelaskan bahwa pajak menjadi isu yang banyak diperdebatkan di kalangan orang Yahudi (1982, p. 114). Itu sebabnya, respons Yesus adalah tidak segera menjawab pertanyaan orang-orang Farisi tersebut dengan jawaban ya atau tidak. Sebaliknya, Yesus meminta mata uang sebagai alat peraga. "Tunjukkanlah kepada-Ku mata uang untuk pajak itu” (ay. 19). Kemungkinan Yesus sudah mengamati gambar dan tulisan yang 
terdapat pada mata uang tersebut sehingga ini dijadikan sebagai alat peraga.

Terkadang alat peraga dibutuhkan agar pendengar menangkap kesan mendalam dari proses pembelajaran tersebut. LeBar (2006, pp. 60, 63) dalam That is Education Christian menyatakan bahwa Comenius yang mempopulerkan penggunaan alat peraga, seperti buku gambar, table-tabel, peta-peta, dan contoh-contoh. Hal ini dilakukan untuk menstimulasi pikiran murid agar memiliki hasrat belajar, minat dari dalam, dan perhatian. Penggunaan alat peraga akan mendorong dan menstimulasi murid-murid mengerti dan memahami pengajaran yang disampaikan. Alih-alih menjawab, justru Yesus bertanya balik kepada orang-orang Farisi sembari menunjukkan mata uang tersebut. "Gambar dan tulisan siapakah ini? (ay. 20).

Menjawab pertanyaan dengan pertanyaan merupakan cara efektif untuk mengajar dan membantu murid-murid berpikir serta mencari jawaban atas pertanyaan mereka sendiri. Freire dan Faundez (1995, p. 51) membahas panjang lebar mengenai belajar bertanya. Dalam pandangan Faundez, mengajukan pertanyaan merupakan bentuk keingintahuan. Guru tidak harus selalu menyediakan seluruh jawaban yang ada ataupun mencari jawaban yang ada. Mengajukan pertanyaan merupakan sarana untuk mengetahui sejauh mana murid telah belajar. Dalam hal ini, guru tidak selalu harus memberikan jawaban yang menyeluruh. Sebaliknya, guru perlu mendorong dan menstimulasi murid-murid agar menemukan sendiri jawaban atas pertanyaan mereka. Yesus menggunakan cara ini sehingga orangorang Farisi heran dan bungkam sehingga tidak dapat membalas jawaban Yesus. Bukankah kecerdasan Yesus sangat teruji?
Dalam situasi demikian, seorang yang tidak bijak dapat sesumbar menjawab tanpa mengamati dan memerhatikan semua aspek. Seorang yang tidak bijak hanya memerhatikan dan mengarahkan pikiran pada menjawab pertanyaan. Seorang yang bijak menyimak lebih mendalam maksud di balik pertanyaan dan bagaimana cara menjawab yang tepat dan benar dengan mempertimbangkan aspek teologis, sosial, dan sebagainya.

\section{Perempuan yang Berzinah (Yoh. 8:1-11)}

Situasi ini lebih berbahaya dibandingkan situasi di atas. Yesus diperhadapkan dengan keputusan yang tidak mudah. Sebab ini menyangkut nyawa dan hidup dua pribadi, yakni wanita yang kedapatan berzinah dan Yesus sendiri. Mencermati ayat 6, maka obyek sesungguhnya yang hendak dijerat adalah Yesus, bukan wanita yang berzinah tersebut. Wanita tersebut dipakai hanya sebagai jalan untuk dapat menyalahkan Yesus. Memang ahli-ahli Taurat dan orang Farisi memaparkan fakta bahwa wanita itu berzinah, tetapi tidak sepenuhnya jujur. Mengacu pada hukum Musa yang terdapat dalam Imamat 201:10, "Bila seorang laki-laki berzinah dengan istri orang lain, yakni berzinah dengan isteri sesamanya manusia, pastilah keduanya dihukum mati, baik laki-laki maupun perempuan yang berzinah itu."

Dalam kasus ini, hanya wanita yang diperhadapkan pada Yesus, sedangkan pria bebas begitu saja. Menarik untuk disimak bahwa ada perbedaan terjemahan antara KJV dan NIV. KJV tidak menyebutkan wanita, "Now Moses in the law commanded us, that such should be stoned: but what sayest thou?" Sedangkan NIV menyebutkan wanita, "In the Law Moses commanded us to stone such women. Now what do you say?" 
Mengacu pada situasi peristiwa tersebut, maka sejatinya laki-laki dan perempuan yang berzinah mendapatkan hukuman yang sama.

Tafsiran Alkitab Masa Kini 3 menjelaskan bahwa niat utama orang Farisi adalah Yesus jatuh bersalah dalam bidang agama maupun sipil (1982, p. 304). Sebab orang Farisi dan ahli Taurat merasa dengki kepada Yesus (Mat. 27:18). Walaupun demikian, Yesus memberikan respons yang tidak biasa dalam hal ini. Dia membungkuk dan menulis (ay. 6), sekalipun mereka terus menerus bertanya kepada-Nya. Namun, pada waktu yang tepat Yesus memberikan jawaban yang mengejutkan dan tidak diduga, "Barangsiapa di antara kamu tidak berdosa, hendaklah ia yang pertama melemparkan batu kepada perempuan itu" (ay. 7).

Jawaban tersebut merupakan jawaban yang tidak biasa. Sebab bukankah yang sedang berusaha menghakimi adalah orang Farisi dan ahli Taurat di mana mereka menganggap dirinya merasa tidak berdosa (Yoh. 9:34)? Bagaimana bila mereka merajam wanita itu dengan batu? Situasi ini memiliki resistensi yang besar sekaligus menegangkan dan menuntut kecerdasan serta hikmat luar biasa. Setidaknya, penulis memikirkan tiga hal dari jawaban Yesus tersebut. Pertama, Yesus memikirkan keadilan bagi wanita tersebut. Wanita ini hendak dihukum rajam, sedangkan pria selingkuhannya bebas. Prinsip keadilan menjadi begitu penting ketika kaum marjinal tidak mendapat tempat dan keadilan selayaknya.

Kedua, Yesus memikirkan dengan saksama jawaban yang hendak disampaikan agar tidak melanggar hukum Romawi dan hukum Taurat. Bila Yesus menyetujui untuk merajam wanita tersebut, maka Yesus akan berhadapan dengan hukum Romawi yang berlaku pada masa itu. Sedangkan bila tidak menyetujuinya, maka Yesus akan berhadapan dengan orang-orang Farisi yang mengetahui isi Taurat. Kanagaraj dan Kemp dalam The Gospel According to John menafsirkan bagian ini dengan cara yang sama bahwa posisi Yesus sangat dilematis. Sebab Yesus harus berhadapan dengan hukum Romawi dan hukum Musa (2002, pp. 224-225). Menurut hemat penulis, posisi dilematis tersebut mendorong Yesus untuk bersikap hati-hati dalam memberikan pernyataan.

Di samping itu, perkataan "tidak berdosa" berbeda dengan "merasa tidak berdosa." Orang Farisi dan ahli Taurat pasti berpikir seribu kali untuk merajam wanita dengan batu karena menganggap diri mereka merasa tidak berdosa, padahal mereka adalah manusia berdosa. Bila orang Farisi dan ahli Taurat memaksa untuk merajam wanita tersebut, maka Yesus terlepas dari tuduhan dan mereka yang akan berhadapan dengan hukum Romawi. Situasi tersebut pasti tidak dikehendaki orang Farisi dan ahli Taurat.

Ketiga, Yesus mengetahui bahwa semua manusia berdosa sehingga tidak layak manusia menghukum sesamanya. Hal ini akan menimbulkan preseden buruk bagi Yesus. Sebab Yesus telah mengajarkan untuk jangan menghakimi sesama (Mat. 7:1). Bila Yesus menyetujui untuk merajam wanita itu, maka Yesus sedang menentang atau menunjukkan inkonsistensi-Nya terhadap ucapan-Nya sendiri. Dengan demikian, Yesus tidak dapat dipercaya sebagai orang yang berotoritas atau berkuasa (Mat. 7:29).

Bagian ini memberikan makna bahwa seorang guru perlu memikirkan terlebih dulu perkataan atau jawaban yang hendak disampaikan agar tidak menimbulkan preseden buruk baginya. Di sini diperlukan sikap sabar dan dapat menahan diri terhadap situasi yang menjebak. Tetapi tegas bila 
berhadapan dengan moralitas buruk dan peduli terhadap kaum yang diperlakukan tidak adil. Oei menyatakan, "Semakin kuat seseorang itu mempunyai hasrat moral (seperti kejujuran, belas kasihan, dan keadilan), semakin kuat identitas moral orang itu yang akan berdampak pada tindakan moral yang diambilnya" (2016, p. 60). Itu sebabnya, Yesus memikirkan jawaban dengan saksama dan tidak terburu-buru mengingat situasi dan kondisi yang menuntutnya demikian. Adiprasetya menyatakan bahwa Yesus amat kritis terhadap orang-orang yang merendahkan kemanusiaan sesamanya, tetapi solider terhadap kaum marjinal (2012, p. 15). Ini tidak berarti Yesus kompromi terhadap moralitas yang buruk. Dalam hal ini, Yesus telah melihat ketimpangan dan ketidakadilan yang terjadi sehingga Yesus memberikan jawaban yang bijak dan pada sasaran yang tepat. Karena itu, langkah praktis yang perlu dilakukan agar tidak membuat keputusan keliru adalah berdiam diri dan melakukan aktivitas lain seperti menulis dan yang lain, sembari memikirkan jawaban yang tepat dan bijak. Hal ini menghindarkan diri dari jebakan dan godaan membuat keputusan yang terburu-buru.

\section{Implikasi Kebijaksanaan Yesus bagi Guru}

Mencermati kebijaksanaan Yesus di atas, maka beberapa poin penting di bawah ini dapat dijadikan sebagai implikasi bagi guru Pendidikan Agama Kristen:

\section{Meminta hikmat dari Allah}

Guru adalah manusia terbatas, sekalipun guru adalah figur yang dapat dijadikan contoh oleh para peserta didik. Itu sebabnya, tugas guru menjadi tidak mudah. Karena itu, guru perlu meminta hikmat kepada Allah dalam membantu persoalan pe- serta didik. Hikmat ini diperoleh bila guru mengenal Allah dan manusia. Tanpa pengenalan kepada Allah dan manusia niscaya guru tidak dapat memberikan solusi yang tepat dan benar. Calvin menyatakan bahwa seluruh hikmat yang benar jika kita memiliki pengetahuan tentang Allah dan pengetahuan tentang diri sendiri (2015, p. 7). Hal senada pun diungkapkan oleh Ferguson bahwa manusia akan menemukan hikmat bila memahami karakter Allah dan relasi-Nya dengan manusia (2003, p. 17).

Pemahaman dan pengetahuan tentang Allah dan manusia hanya dapat diperoleh melalui Alkitab. Sebab setidaknya Alkitab mengungkapkan penyataan diri dan karakter Allah secara langsung kepada manusia. Melalui Alkitab pula diungkapkan natur manusia. Alkitab juga yang memperkenalkan manusia pada natur keilahian dan kemanusiaan Yesus Kristus. Mempelajari hidup Yesus akan menolong guru untuk bertindak tepat dalam situasi tertentu. Hal ini akan menolong guru untuk terhindar dari sikap memihak. Karena itu, dibutuhkan hikmat untuk membuat keputusan yang bijak agar guru dapat memilah mana yang benar dan mana yang tidak. Walaupun guru perlu juga mengedepankan sikap belas kasih.

Itu sebabnya, mempelajari Alkitabterutama Yesus Kristus-akan membantu guru menemukan prinsip dan implikasi yang tepat dalam bertindak dan bersikap. Salah satu yang perlu disimak adalah bagaimana Yesus memiliki sikap belas kasihan kepada para peserta didik, sekalipun ia tidak mengabaikan sikap tegas dalam bertindak. Elia menjelaskan bahwa belas kasihan Yesus cukup mendominasi dalam kehidupan dan pelayanan-Nya (2001, p. 252). Itu sebabnya, nampaknya Yesus menaruh belas kasihan pada wanita yang kedapatan berbuat zinah, 
sekalipun Yesus tidak membenarkan perbuatan wanita tersebut.

Sikap belas kasihan perlu dimiliki seorang guru dalam menyikapi murid. Hal ini dapat dilatih dengan mendengarkan suara hati sekalipun diperlukan daya kritis untuk membedakan pertimbangan yang benar dan tidak. Listiati (2018) menyatakan bahwa suara hati merupakan pertimbangan akal budi untuk menentukan manakah yang benar dan tidak dari tindakan yang diambil. Perlu disadari bahwa melatih mendengarkan suara hati tidak mudah di tengah-tengah tuntutan tugas dan pekerjaan yang menumpuk secara administratif. Seringkali suara hati (hati nurani) tidak diperhatikan karena adanya aturan-aturan yang mengikat. Mendengarkan suara hati menjadi penting dalam hubungan dengan peserta didik. Peserta didik adalah individu-individu yang perlu disentuh dengan hati, bukan sekadar aturan. Memang aturan baik dilaksanakan agar terjadi ketertiban dan keteraturan. Namun, aspek hati nurani perlu juga diperhatikan dalam situasi-situasi krusial dan dilematis. Sidjabat mengutip pendapat Hallesby yang menyatakan bahwa suara hati turut memberi penilaian terhadap masalah yang sedang, telah, dan akan dikerjakan apakah itu berkenan kepada Allah atau tidak (1996, p. 256).

Itu sebabnya, pengertian dan hati nurani guru perlu dibersihkan. Ibrani 9:14 menyatakan,

Betapa lebihnya darah Kristus, yang oleh Roh yang kekal telah mempersembahkan diri-Nya sendiri kepada Allah sebagai persembahan yang tak bercacat, akan menyucikan hati nurani kita dari perbuatanperbuatan yang sia-sia, supaya kita dapat beribadah kepada Allah yang hidup.
Dalam hal ini Yesus pun mengembangkan relasi dengan Bapa sehingga apapun yang dilakukan Yesus mengacu pada kehendak Bapa (Mat. 26:42; Luk. 22:42; Yoh. 6:40). Dengan demikian, guru Pendidikan Agama Kristen perlu mengembangkan relasi dengan Allah dalam firman dan merelakan dirinya dipimpin Roh Kudus untuk melatih mendengarkan suara hati. Cara ini merupakan salah satu cara untuk melatih suara hati. Pengembangan relasi dengan Allah berguna bagi guru dalam membuat pertimbanganpertimbangan etis berkenaan dengan persoalan peserta didik sehingga guru dapat memikirkan dengan saksama setiap hal untuk kemajuan dan perkembangan diri peserta didik. Senada dengan hal ini, Listiati memberikan langkah praktis untuk melatih suara hati, yaitu dengan meluangkan waktu untuk memeriksa batin, rela dipimpin Roh Kudus, membaca Alkitab, dan belajar dari pengalaman orang kudus (2018). Petty pun menyatakan hal yang sama bahwa seseorang yang mencari hikmat perlu belajar dari orang lain yang berhikmat untuk menghidupi karakter Allah (2004:183). Amsal 13:20 menyatakan, "Siapa bergaul dengan orang bijak menjadi bijak, tetapi siapa berteman dengan orang bebal menjadi malang."

Dalam hal ini, ada baiknya guru PAK meminta nasihat juga dari orang yang dianggap memiliki hikmat. Sebab peserta didik yang memiliki persoalan dalam diri atau dengan proses belajar dapat dibimbing oleh guru karena guru memiliki kepekaan atas perubahan perilaku yang terjadi. Sebab tidak semua peserta didik dapat terbuka terhadap persoalan pribadi yang dialami. Karena itu, dibutuhkan sebuah kepekaan terhadap perubahan yang terjadi pada diri peserta didik. Guru dapat berinisiatif untuk memanggil atau berbincang secara informal di luar kelas agar tidak terkesan bahwa guru sedang 
mengamati atau menginterogasi. Guru yang bijaksana dapat menggunakan momentum yang tepat untuk mendalami persoalan peserta didik.

\section{Membaca Sebagai Gaya Hidup}

Perlu disadari tidak semua orang menyukai, bahkan menikmati kebiasaan membaca. Sutikno dalam Pendidikan Sekarang dan Masa Depan menjelaskan rendahnya minat membaca di Asia Timur, terutama Indonesia. Indonesia menduduki peringkat terendah dalam membaca di bawah Filipina dan Thailand (2006, pp. 93-94). Namun, sebagai seorang guru, membaca merupakan hal yang sangat penting untuk dilakukan. DePorter dan Hernacki (2004) dalam Quantum Learning membahas kiat-kiat membaca secara cepat. Kiat-kiat tersebut dapat digunakan bagi pembaca yang berminat mengembangkan kemampuan membaca. Demikian juga Dryden dan Vos dalam Revolusi Cara Belajar (2000) membahas prinsip-prinsip membaca secara cepat dan selektif. Kedua buku tersebut dapat menolong guru meningkatkan kemampuan membaca. Selain itu, Sihotang mengulas secara praktis kemampuan membaca secara kritis (2019). Menurut Hendricks, pemimpin adalah pembaca, dan pembaca adalah pemimpin (2013, p. 31). Selanjutnya, Hendricks menulis bahwa diperlukan waktu satu jam untuk membaca, setengah jam digunakan untuk membaca dan setengah jam selanjutnya digunakan untuk merenungkan bacaan tersebut. Selain itu, bergaullah dengan orang-orang yang senang membaca (2013, p. 32).

Membaca merupakan salah satu kegiatan yang dapat dilakukan seorang guru di mana saja dan kapan saja. Artinya guru perlu meluangkan waktu untuk membaca secara khusus, sekalipun di tengah-tengah kesibukan. Meluangkan waktu secara konsisten untuk membaca akan menolong guru mengembangkan aspek intelektual. Bila memungkinkan, maka sekolah dapat membeli satu buku setiap bulan yang diberikan kepada setiap guru Pendidikan Agama Kristen. Selanjutnya, buku tersebut didiskusikan bagaimana mengimplementasikan sesuai kebutuhan di sekolah. Alangkah lebih baik bila guru pun dapat mengalokasikan dana pribadi untuk membeli buku baru sehingga pengetahuan bertambah luas dan dapat menerima informasi baru. Salah satu cara untuk mengembangkan kebiasaan membaca adalah memahami tujuan membaca. Setiawan menyatakan bahwa seseorang akan memperoleh apa yang ditentukan sebagai tujuan dalam membaca buku (2013, p. 105). Guru PAK perlu memahami tujuan membaca agar hal ini menjadi suatu kebiasaan yang dilakukan setiap hari. Karena itu, guru PAK perlu memaksakan diri membaca setiap hari. Setidaknya, perlu mengalokasikan waktu 1-2 jam untuk membaca.

\section{Membuat Keputusan Bijak}

Membuat keputusan yang tepat ketika peserta didik mengalami pertengkaran tidak mudah. Dibutuhkan kecermatan dan ketelitian untuk mengerti sejauh mana kebenaran setiap perkataan dan informasi yang diberikan peserta didik. Guru perlu bersikap bijak dan hati-hati agar tidak terburuburu membuat kesimpulan berdasarkan informasi yang diterima. Setidaknya, ada dua hal yang perlu dilakukan guru agar keputusan yang dibuat tepat.

Pertama, mendengarkan. Mendengar merupakan salah satu cara efektif untuk mengetahui permasalahan dengan tepat. Guru perlu mendengarkan peserta didik yang bertengkar dengan saksama dari kedua 
pihak, sehingga guru memiliki informasi yang komprehensif. Yakobus 1:19 menyatakan, "Hai saudara-saudara yang kukasihi, ingatlah hal ini: setiap orang hendaklah cepat untuk mendengar, tetapi lambat untuk berkata-kata, dan juga lambat untuk marah." Gibb dan Nichols menyatakan, "Seseorang yang ingin menjadi pendengar yang baik ia harus mencoba untuk mendapatkan inti pembicaraan, jalinan benang utama, gagasan, prinsip, konsep, dan generalisasi" (1992, p. 81). Mengetahui fakta merupakan elemen penting, tetapi mengetahui gagasan utama dari yang disampaikan merupakan elemen paling penting. Guru yang bijaksana perlu cermat dalam meneliti dan mendengarkan uraian peserta didik.

Kedua, bertanya. Mengajukan pertanyaan merupakan usaha guru untuk membuat keputusan yang tepat dan benar. Proses ini perlu dilakukan agar guru mengetahui secara mendalam kondisi dan situasi peserta didik sesungguhnya. Tong memberikan pendapatnya mengenai teknik bertanya, yaitu guru perlu menggoncangkan pikiran peserta didik yang salah tetapi beku,

\section{DAFTAR RUJUKAN}

Calvin, Yohanes. (2015). Institutio: Pengajaran Agama Kristen. Jakarta: BPK Gunung Mulia.

DePorter, Bobbi, Hernacki, Mike. (2004). Quantum Learning. Bandung: Kaifa.

Dryden, Gordon., Vos, Jeannette (2000). Revolusi Cara Belajar. Bandung: Kaifa.

Elia, Heman. (2001). Kehidupan Alam Perasaan Yesus Kristus: Teladan Sempurna Bagi Para Pendidik Kristen. Veritas 2(2), 237-244.

Ensiklopedia Alkitab Masa Kini Jilid I. (1992). Jakarta: YKBK. merangsang atau menstimulus pikiran peserta didik untuk memikirkan kemungkinankemungkinan di luar apa yang mereka pikirkan, dan di dalam pertanyaan-pertanyaan tersebut guru memiliki kepastian pegangan dengan menjawab pertanyaan secara tegas dan tepat (1995, p. 70). Dengan kata lain, guru seyogianya memiliki tujuan ketika mengajukan pertanyaan-pertanyaan agar peserta didik menyadari kekeliruan dari tindakan, perkataan, dan sikap, di samping untuk mendalami situasi yang terjadi.

\section{KESIMPULAN}

Seorang guru Pendidikan Agama Kristen perlu memerhatikan dan memiliki beberapa aspek yang dapat dijadikan sebagai landasan untuk menjadi guru yang bijaksana, yaitu aspek spiritual, intelektual, aktualisasi yang tepat berupa keterampilan dalam membuat keputusan yang bijak. Setidaknya, memiliki ketiga aspek tersebut dapat menjadikan guru Pendidikan Agama Kristen mampu menolong peserta didik bertumbuh dalam suasana akademis yang sehat.

Ferguson, Sinclair B. (2003). Menemukan Kehendak Allah. Surabaya: Penerbit Momentum.

Freire, Paulo., Antonio Faundez. (1995). Belajar Bertanya Pendidikan yang Membebaskan. Jakarta: BPK Gunung Mulia.

Gibb dan Nichols, et. al. (1992). Komunikasi. Semarang: Dahara Prize.

Green, Michael. (2000). The Message of Matthew. England: Inter-Varsity Press Hendricks, Howard. (2013). Mengajar Untuk Mengubah Hidup. Jakarta: Yayasan Gloria. 
(1992a). Matthew Henry's

Commentary on The Whole Bible Vol. 3.

Peabody: Hendrickson Publishers. . (1992b). Matthew Henry's

Commentary on The Whole Bible Vol. 6. USA: Hendrickson Publishers.

Ismail, Andar. (2014). Selamat Mengikut Dia! Jakarta: BPK Gunung Mulia.

Jonch, Christian. (2007). Yesus Sebagai Guru: Studi Injil Yohanes. Veritas 8(2): 257-276.

Kanagaraj, Jey., Kemp, lan. (2002). The Gospel According to John. Singapore: Asia Theological Association.

Karnawati K, H Hosana, I Putu Ayub Darmawan. (2019). Lingkungan Proses Pembelajaran Yesus. Veritas Lux Mea 1(2), 76-89.

LeBar, Lois E. (2006). That is Education Christian. Malang: Gandum Mas.

Listiati, Ingrid. (2018). Tentang Suara Hati. dari website:

http://www.katolisitas.org/tentangsuara-hati/

Morris, Leon. (2006). Teologi Perjanjian Baru. Malang: Gandum Mas.

Notomiharjo, Robbyanto. (1995). Yesus Sebagai "Tuhan" (Kyrios): Tinjauan Perkembangan Konsep Dalam Perjanjian Baru. Jurnal Pelita Zaman 10(2).

https://alkitab.sabda.org/resource.php? topic $=569$ \&res $=j p z$

Nugroho, Adi. (2019). Siswa Berkebutuhan Khusus di Bekasi Diduga Dianiaya Guru Hingga Memar. dari website: https://www.merdeka.com/peristiwa/sis wa-berkebutuhan-khusus-di-bekasididuga-dianiaya-guru-hinggamemar.html.

Oei, Amos Winarto. (2016). Pemahaman Identitas Moral Dalam Meningkatkan Kemampuan Pengambilan Keputusan
Etis Bagi Para Peserta Didik Pendidikan Agama Kristen. Societas Dei 3 (1), 55-76.

Petty, James C. (2004). Step by Step. Surabaya: Penerbit Momentum.

Prasetya, Yoas. (2012). Yesus dan Kekerasan: Memahami Narasi Kekerasan Dalam Alkitab. Forum Biblika 26, 12-26.

Price, J.M. (2011). Yesus Guru Agung. Bandung: Lembaga Literatur Baptis.

Rosadi, Saud. (2019). Guru Terduga Penganiaya Murid PAUD di Samarinda Kabur ke Taiwan. Dari website: https://www.merdeka.com/peristiwa/gu ru-terduga-penganiaya-murid-paud-disamarinda-kabur-ke-taiwan.html.

Rhodes, Ron. (2016). Berdiskusi Dari Alkitab Dengan Saksi-saksi Yehuwa. Malang: Literatur SAAT.

Setiawan, Agus (2013). Baca Kilat Kiat Membaca 1 Halaman/Detik: Jakarta: Gramedia.

Sidjabat, B.S. (2011). Mengajar Secara Profesional. Bandung: Kalam Hidup (1996). Strategi Pendidikan Kristen. Yogyakarta: Andi Offset.

Sihotang, Kasdin. (2019). Berpikir Kritis Kecakapan Hidup di Era Digital. Yogyakarta: Penerbit Kanisius.

Sugiyono. (2014). Memahami Penelitian Kualitatif. Bandung: Alfabeta.

Sutanto, Hasan. (2004). Perjanjian Baru Interlinear Yunani-Indonesia dan Konkordansi Perjanjian Baru (PBIK). Jakarta: Lembaga Alkitab Indonesia. . (2007). Hermeneutik: Prinsip dan Metode Penafsiran Alkitab. Malang: Literatur SAAT.

Sutikno, Sobry. (2006). Pendidikan Sekarang dan Masa Depan. Mataram: NTP Press 
Tafsir Alkitab Masa Kini (Jilid 3) (1982). Tong, Stephen. (1995). Arsitek Jiwa II. Jakarta: Yayasan Komunikasi Bina Jakarta: Lembaga Reformed Injili Kasih. Indonesia.

Tenney, Merrill C. (2013). Survey Perjanjian Zodhiates, Spiros. (1992). The Complete Baru. Malang: Gandum Mas.

Word Study Dictionary New Testament. USA: AMG International. 